\title{
Finnish Attitudes towards Immigrants in 1987-1999
}

\author{
MAGDALENA JAAKKOLA \\ Ph.D., Docent in Sociology \\ University of Helsinki \\ Senior Researcher \\ Rehabilitation Foundation
}

\section{Abstract}

The attitudes of Finns towards foreigners were more negative during the time of widespread unemployment in 1993 than before (1987) or afterwards (1998-1999). Interviews with about 1,000 persons representing the entire population showed that the most educated and those who were personally acquainted with migrants were more positive - in accordance with the contact theory - than the others in their attitudes toward refugees and foreign job seekers and all the ethnic groups mentioned. Those with little education, pensioners, the unemployed, men, supporters of the Central Party and those living in rural areas had more negative attitudes and believed - in accordance with the conflict theory - that they would take jobs and social benefits away from the Finns. In 1998 over one-third of the young men living in the rural areas supported the actions of skinheads against immigrants.

Keywords: Attitude, immigrant, refugee, Finnish

\section{Growth of the alien population}

Towards the end of the 1800 s and in the beginning of the 1900 s some 400,000 emigrants moved from Finland to America. Migration from Sweden and Norway was even more extensive, and a large number of emigrants from Denmark, too, headed to America (Kero 1986, 27). Finland does indeed differ from the other Nordic countries specifically with regard to the migration movement that followed World War II. As a result of an exceptionally radical structural change, more than 610,000 Finns moved abroad in $1946-80$, three-quarters of them to Sweden. By the beginning of the $1980 \mathrm{~s}$, close to half had returned. After this immigration has become more common than emigration. 
In 1987 there were less than 18,000 foreign nationals in Finland, over half of whom originated in Western Europe. There were only 900 refugees and a mere 46 were seeking asylum in Finland. By 1993 the number of foreign nationals had tripled and the number of refugees was more than ten-fold. Also, the ethnic and social structure of the alien population had undergone a change, as the proportion of Eastern Europeans, Asians and Africans was growing. In 1990-1993 more asylum seekers $(2,000-3,700)$ than previously or subsequently arrived in Finland annually - with the exception of the period following the Russian revolution, when (in 1922) the number of Russian, Eastern Karelian and Ingrian refugees in Finland peaked at 33,500 (Engman 1987).

In spite of the rapid growth rate in the number of immigrants, there are still very few immigrants in Finland. Table 1 shows that 85,060 foreign citizens were living in Finland in 1998 - only 1.7 percent of the population. They consisted of 156 different nationalities. More people were foreign-born: 125,050 , or 2.4 percent of the population. Some had become Finnish citizens. There were approximately 16,500 refugees living in as many as 131 municipalities.

Table 1. Number of foreign citizens, refugees and asylum seekers at the end of 1987, 1993 and 1998 and the proportion of foreign citizens of the population as a whole (\%).

\begin{tabular}{ccccc}
\hline & Foreign citizens \% & Refugees & $\begin{array}{c}\text { Asylum seekers } \\
\text { annually }\end{array}$ \\
\hline 1987 & 17724 & 0,4 & 900 & 49 \\
1993 & 55587 & 1,1 & 10050 & 2023 \\
1998 & 85060 & 1,7 & 16434 & 1272 \\
\hline
\end{tabular}

In May 1999, during the war in Kosovo, Finland accepted nearly one thousand (963) Kosovan Albanians in excess of the refugee quota (650). Some returned to Kosovo voluntarily when the war ended in the beginning of June 1999.

Table 2 shows that at the end of 1998 , nearly one-third of the foreigners living in Finland were Estonian or Russian nationals. There were a total of 38,000 people who were born in the former Soviet Union, some of whom had already received Finnish citizenship. Some 21,000 of them were Ingrian-Finnish remigrants, who, as a result of a statement (on April 10, 1990) by then-president Mauno Koivisto, were able to enter the country more easily than others who wanted to immigrate to Finland. At first it was enough to have one Finnish grandparent. Now it is required that the documentation of at least two grandparents is marked "Finnish citizen" (Ministry of Labor 1998). 
At the end of 1998 , there were 28,000 people who had been born in Sweden, but only less than 8,000 Swedish nationals. Many of them are Swedish-Finnish remigrants or their descendants. There were over 5,000 Somalian nationals and close to 3,000 former Yugoslavian nationals.

Table 2. Foreign citizens according to nationality at the end of 1993 and 1998.

\begin{tabular}{|c|c|c|c|c|c|c|}
\hline \multirow[t]{2}{*}{$\begin{array}{l}\text { Top originating } \\
\text { countries }\end{array}$} & \multicolumn{4}{|c|}{ Foreign citizens } & \multicolumn{2}{|c|}{$\begin{array}{l}\text { Foreign-born } \\
\text { people }\end{array}$} \\
\hline & 1993 & & 1998 & & 1998 & \\
\hline Russia & 5828 & & 16861 & & 1612 & \\
\hline Estonia & 5893 & & 10340 & & 6974 & \\
\hline Former Soviet Union & 7468 & 19189 & 3628 & 30829 & 29777 & 38363 \\
\hline Sweden & 6528 & & 7756 & & 27768 & \\
\hline Somalia & 2883 & & 5371 & & 4138 & \\
\hline Yugoslavia & 2073 & & 2935 & & 3801 & \\
\hline Iraq & 846 & & 2670 & & 2636 & \\
\hline Germany & 1576 & & 2072 & & 3322 & \\
\hline Gt Britain, Northern & & & & & & \\
\hline Ireland & 1676 & & 2058 & & 2525 & \\
\hline United States & 1754 & & 2001 & & 2882 & \\
\hline Vietnam & 1403 & & 1964 & & 2768 & \\
\hline Total & 55587 & & 85060 & & 125050 & \\
\hline
\end{tabular}

\section{Theories to explain changing attitudes}

Two opposing propositions have been presented regarding the impact of the number of immigrants on attitudes. According to the so-called conflict theory, discrimination and anti-immigrant attitudes increase when different groups come in contact with each other, when the relative size of the minority increases, and the minority and majority compete for the same limited resources, for example jobs, social benefits or the preference of the opposite sex (Lange and Westin 1981, 59-62; Hernes and Knudsen 1990). According to the so-called contact theory, on the other hand, prejudices begin to wane when contact between the minority and majority increases, becomes more personal and manyfaceted, and the contacts are forged between people with an equally valued status. The positive impact of contacts is thought to occur, among other things, because through them, people obtain more information about another group and learn to understand the behavior of its members (Duckitt 1992; Liebkind and McAlister 1999; Liebkind, Haaramo and Jasinskaja-Lahti 2000).

Both the conflict and contact theories are supported by studies conducted in the Nordic countries and elsewhere in Europe. Attitudes towards immigration depend on how 
much people have had to do with immigrants, and on whether people see immigrants as competitors, for example with regard to jobs and social benefits (Trankell 1974; Westin 1987; Lange 1995; Hernes and Knudsen 1994; Gaasholt and Togeby 1995).

The conflict theory was also supported by studies carried out in Finland in 1987 and 1993 (Jaakkola 1989, 1994, 1995). The increase in the number of foreigners and the unexpected growth in the number of asylum seekers in the first years of the 1990s coincided with a difficult period. Following the economic boom of the 1980s Finland had plunged into recession and mass unemployment - unemployment quadrupled from five percent in 1987 to 20 percent in 1993.

During the recession Finns justified their attitudes towards refugees and other foreigners more frequently by referring to competition for jobs and social benefits. In accordance with the conflict theory, this was also connected to prejudices that manifested themselves in other ways among all population groups. The contact theory, too, received reinforcement: Even during the recession, those who personally knew foreigners living in Finland had the most positive attitude towards foreigners in general (Jaakkola 1995).

The social situation has changed again and the number of immigrants has grown even though fewer asylum seekers enter Finland annually than during the recession period. Unemployment is also half of what it was in 1993. In 1998, "only" eleven percent of the workforce was still unemployed. However, the unemployment rate was double compared with the 1987 rate.

\section{Objective and material of the study}

The objective of the study is to describe Finnish attitudes towards the alien population now and in the past, as well as how these attitudes changed during the recession and afterwards as the economy revitalized and the number of foreigners increased. The following aspects will be examined:

1) Attitudes towards immigrants who come to Finland for different reasons: What are the attitudes towards immigrants who are received for humanitarian reasons, such as refugees and the immigrants who are "useful" for us, like language teachers and restaurant owners? What was the attitude towards the Kosovo refugees? What is the attitude towards foreign jobseekers and those who immigrate for economic reasons?

2) Are foreigners seen as competitors for jobs and social benefits even as the economy is being revitalized after the recession?

3) What is the attitude towards the immigration of different nationalities? Have the attitudes changed as the ethnic structure of the immigrant population has changed? 
4) Does racism occur in Finland and what are the attitudes of Finns towards ethnic cleansing and skinhead activity against foreigners? Has racism increased or decreased as the number of immigrants has grown?

Secondly, the factors that influence the attitudes towards foreigners will be examined:

1) How do various underlying factors - age, gender, education, occupation, place of residence and political views - influence attitudes?

2) Do personal contacts influence attitudes towards foreigners in accordance with the contact hypothesis?

3) What is the order of importance of factors that explain attitudes towards foreigners?

This article is based on the personal interviews of approximately one thousand people, conducted by Gallup Finland in 1987, 1993 and 1998 at the interviewees' homes in different parts of Finland. The 1999 material is based on telephone interviews conducted by Gallup Finland in May during the war in Kosovo. All studies represent the Finnish population over fifteen years of age, with the exception of the Åland Islands, in geographic area and industrial, age and gender structure. Since over half of all immigrants were living in the Helsinki metropolitan area, special material was gathered there in $1993(\mathrm{~N}=488)$ and $1998(\mathrm{~N}=390)$.

\section{Present and past attitudes towards foreigners in Finland}

\section{Attitudes towards the reasons for immigrating}

Interviews conducted in 1998 and 1999 indicated that Finnish attitudes towards immigrants became more positive after the recession year of 1993. They were still not as positive as in 1987 when there were very few foreigners in Finland. In 1998 and 1999, however, the attitude towards foreign jobseekers was more positive than it was during the previous economic boom in 1987.

Compared to the recession year, Finnish attitudes in 1998 were more positive towards immigrants who were accepted on humanitarian grounds and towards those who came for economic reasons. The change towards positive attitudes was greatest particularly with regard to foreign jobseekers, students and language teachers. 
The attitude towards allowing in people who are 'useful' for Finland, such as tourists, scientists and experts, students, entrepreneurs and adoptive children (after all, it is difficult to adopt children from Finland) was more positive in each study year than was the attitude towards immigrants who were accepted on humanitarian grounds, fleeing war and environmental catastrophe, or those persecuted on the basis of politics, religion or race, as well as the starving people of developing countries. Figure 1 shows that in 1998 the attitude towards refugees, on the other hand, was more positive than towards foreign jobseekers and those immigrating for economic reasons.

Figure 1. Attitudes to different immigrant groups in $1998(\%)$.

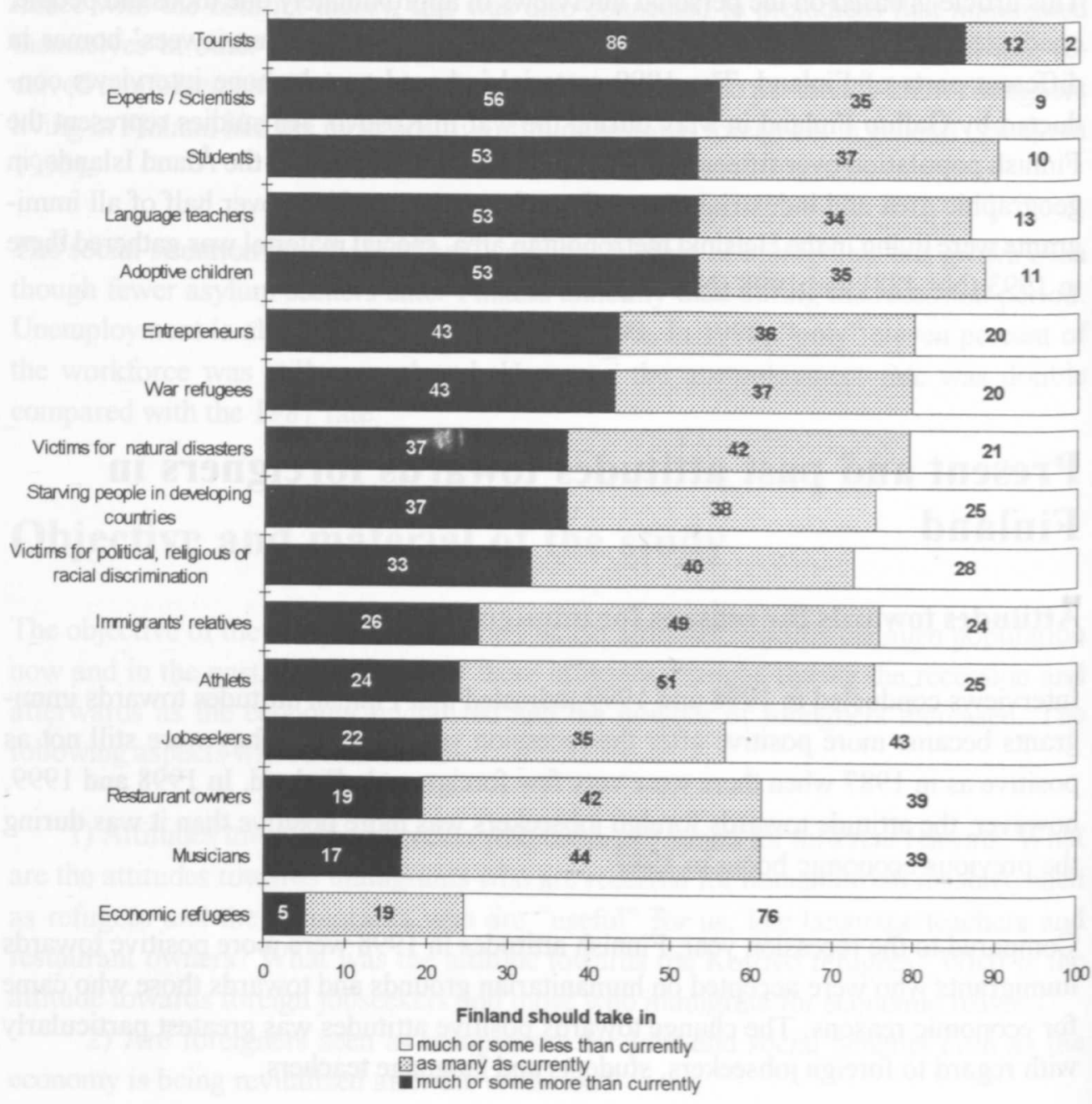




\section{Attitudes towards foreign jobseekers}

Table 3 shows that after the economy picked up in 1999, nearly two-thirds (62\%) of Finns held the opinion that Finland should take in foreign jobseekers ("much/somewhat") more ("than currently") or the same number as before. During the recession and mass unemployment in 1993 only a little over one-third was prepared to take in foreign jobseekers at least to the same extent as previously. The proportion of those who most radically opposed the immigration of foreign jobseekers ("much fewer should be accepted") decreased particularly noticeably after the recession, and the proportion of those who supported the current situation and of those who supported increasing the number of foreign jobseekers, increased. The attitudes towards foreign workers became even more positive between 1998 and 1999. The change may be explained with the improvement in the employment situation. It is significant, for one, because Finland may soon face a labor shortage.

Table 3. Attitudes towards accepting foreign jobseekers and refugees in 1987, 1993, 1998 and $1999(\%)$

\begin{tabular}{|c|c|c|c|c|c|c|c|c|c|}
\hline $\begin{array}{l}\text { Should Finland accept } \\
\text { foreign jobseekers }\end{array}$ & 1987 & & 199 & & 1998 & & 1999 & & $\begin{array}{c}\text { Change } \\
\text { 1993-1999 }\end{array}$ \\
\hline Much more than currently & 5 & & 3 & & 4 & & 4 & & +1 \\
\hline Somewhat more & 16 & & 11 & & 17 & & 20 & & +9 \\
\hline Same as before & 34 & 55 & 24 & 38 & 34 & 59 & 38 & 62 & +14 \\
\hline Somewhat less & 24 & & 24 & & 24 & & 20 & & -4 \\
\hline Much less than currently & 20 & & 37 & & 18 & & 12 & & -25 \\
\hline Can't say & 2 & & 1 & & 2 & & 6 & & +5 \\
\hline Total & 100 & & 100 & & 100 & & 100 & & \\
\hline N & (1088) & & (1035) & & $(1020)$ & & (1007) & & \\
\hline $\begin{array}{l}\text { Should Finland accept } \\
\text { refugees }\end{array}$ & 1987 & & 1993 & & 1998 & & & & $\begin{array}{c}\text { Change } \\
1993-1998\end{array}$ \\
\hline Much more than currently & 11 & & 4 & & 3 & & & & -1 \\
\hline Somewhat more & 30 & & 16 & & 16 & & & & 0 \\
\hline Same as before & 40 & 81 & 34 & 54 & 45 & 64 & & & +11 \\
\hline Somewhat less & 8 & & 20 & & 21 & & & & +1 \\
\hline Much less than currently & 8 & & 24 & & 14 & & & & -10 \\
\hline Can't say & 2 & & 1 & & 1 & & & & 0 \\
\hline $\begin{array}{l}\text { Total } \\
\mathrm{N}\end{array}$ & $\begin{array}{c}100 \\
(1088)\end{array}$ & & (1035) & & $\begin{array}{c}100 \\
(1020)\end{array}$ & & & & \\
\hline
\end{tabular}




\section{Attitudes towards refugees}

Table 3 also shows that in 1998 approximately two-thirds (64\%), and during the recession year, only just over half of all Finns were of the opinion that Finland should take in refugees ("much/somewhat") more ("than currently") or as many as before. In 1987, during the previous economic boom, attitudes were much more positive than they were during the recession or afterwards (Jaakkola 1999, 26).

Also, attitudes towards annual refugee quotas has undergone a change. In 1987 over half of the interviewees supported a quota of less than 500 refugees, and one out of five supported taking in at least 1,000 refugees annually. In the recession year of 1993 almost one-third of the respondents already supported taking in at least 1,000 refugees. People had become accustomed to higher refugee numbers by then. In 1993 Finland took in a total of 3,689 refugees, including quota refugees $(500)$, those who were granted residency for the reason of needing asylum or protective status, as well those who arrived in the country under the auspices of the family unification program (Monitori 2/99).

In 1998 and 1999 Finns supported even larger refugee quotas. In 1998, 41 percent of respondents already supported a higher quota of at least 1,000 , in excess of the current quota (600). At that point, however, Finland took in only 958 refugees, or nearly 3,000 fewer than in the recession year of 1993. In 1999, when the refugee quota was 650, nearly as many people ( 30 percent) as in the previous year supported taking in at least 1,000 refugees, but only fewer than one-fourth supported setting the refugee quota at a 2,000 minimum.

The Kosovo refugees of 1999 were accepted with a much more positive attitude than quota refugees. In 1999 two-thirds of Finns were prepared to take in at least 1,000 Kosovo Albanians fleeing the Serbs' ethnic cleaning and NATO's bombings - and nearly 1,000 refugees were taken in before the end of the war. One in three Finns was prepared to take in at least 5,000 and one in six (17\%) at least 10,000 Kosovo refugees. Daily images of the shocking floods of refugees and the refugee camps certainly influenced this, along with public statements by the president and numerous cabinet ministers who proposed accepting up to 10,000 Kosovo refugees in Finland (Jaakkola 1999, 52-63).

In Sweden, too, the attitude towards immigration has become more positive after the economic recession. According to researchers at the University of Gothenburg, in 1992 two-thirds (65\%) and in $199359 \%$ of Swedes held the opinion that it would be very/ fairly acceptable to take in fewer refugees than were currently arriving. In 1998 only half of all Swedes had such a negative attitude towards accepting refugees (Demker and Malmström 1999). According to a study by Sifo, negative attitudes towards immigration in general, not just refugees, peaked in 1997 and 1998, and were more negative 
than in 1989 before the recession and in 1999 following the recession. Director of research Anders Leion thinks that in addition to the improving economic situation, the need for help that was created by the Kosovo war softened attitudes in Sweden, too, in 1999. A third explanation is not as idealistic: As Sweden has tightened its immigration policies and is taking in fewer immigrants, they are no longer considered as "dangerous" as before (Sifo 1999).

\section{Perceived competition for jobs and social benefits}

During the recession Finns justified their attitudes towards immigrants more often than previously by saying that immigrants took away jobs and social benefits from Finns. These explanations were still used after the recession, in 1998, more frequently than in 1987, before the recession, when there were few foreigners in Finland and the proportion of the unemployed was half of what it is today. In studies conducted in Sweden, the questions presented in Table 4 are thought to measure the socio-economic threat experienced by respondents (Trankell 1974; Westin 1984; Westin 1987; Lange 1995).

Table 4. Perceived competition for jobs, social benefits and standard of living in 1987, 1993 and 1998 (\%).

\begin{tabular}{cccccc}
\hline $\begin{array}{c}\text { Completely } \\
\text { agree }\end{array}$ & $\begin{array}{c}\text { Partly } \\
\text { agree }\end{array}$ & $\begin{array}{c}\text { Partly } \\
\text { disagree }\end{array}$ & $\begin{array}{c}\text { Completely } \\
\text { disagree }\end{array}$ & Can't say & $N$ \\
\hline
\end{tabular}

Finland must primarily ensure that there is enough work for at least its own population
$\begin{array}{lllllll}1987 & 68 & 24 & 7 & 1 & 1 & 100(1088) \\ 1993 & 69 & 23 & 6 & 1 & 1 & 100(1035) \\ 1998 & 57 & 31 & 8 & 2 & 0 & 100(1020)\end{array}$

Because we Finns built this country, it is completely fair that we are the first to benefit from our high standard of living

$\begin{array}{lllllll}1987 & 24 & 32 & 26 & 16 & 2 & 100(1088) \\ 1993 & 43 & 34 & 16 & 6 & 1 & 100(1035) \\ 1998 & 39 & 33 & 19 & 7 & 2 & 100(1020)\end{array}$

Many foreigners come to Finland just to take advantage of our social benefits

$\begin{array}{lllllll}1987 & 15 & 31 & 32 & 18 & 4 & 100(1088) \\ 1993 & 43 & 33 & 17 & 5 & 1 & 100(1035) \\ 1998 & 32 & 39 & 19 & 8 & 2 & 100(1020)\end{array}$

If unemployment grows, some of the foreigners should be sent back

$\begin{array}{lllllll}1987 & 13 & 17 & 28 & 39 & 3 & 100(1088) \\ 1993 & 26 & 26 & 28 & 17 & 3 & 100(1035) \\ 1998 & 17 & 27 & 33 & 20 & 3 & 100(1020)\end{array}$

Immigration to Finland should be limited as long as there is unemployment in the country

$\begin{array}{llllcll}1987 & 26 & 32 & 26 & 15 & 1 & 100(1088) \\ 1993 & 45 & 31 & 16 & 7 & 1 & 100(1035) \\ 1998 & 28 & 36 & 23 & 11 & 2 & 100(1020)\end{array}$


Table 4 shows that after the recession, Finns no longer thought that the jobs and high standard of living in Finland were their self-evident right and privilege. They also did not express doubts as frequently about "many foreigners coming to Finland just to take advantage of our social benefits."

Particularly often during the recession, Finns held the opinion that immigration to Finland should be curbed as long as there was unemployment. In 1998 one out of six Finns thought that "if unemployment grows, some of the foreigners should be sent back." During the recession, up to one out of four respondents held such a radical opinion.

According to all these questions, Finns were less worried in 1998 about their own employment and standard of living than they were during mass unemployment in 1993 (Figure 2). A scale measuring the perception of economic competition was made up of the statements in Table 4, which were very significantly connected to one another. The reliability of the scale was high (Cronbach's alpha $=.82$ ). The study showed according to other questions as well, that those who justified their negative attitudes by mentioning economic competition had a more negative attitude towards all immigrant groups than did those who did not use perceived competition as a justification for their attitudes.

Figure 2. Experiences of socioeconomic threat among the Finns according to age in 1987, 1993 and 1998, (\%).

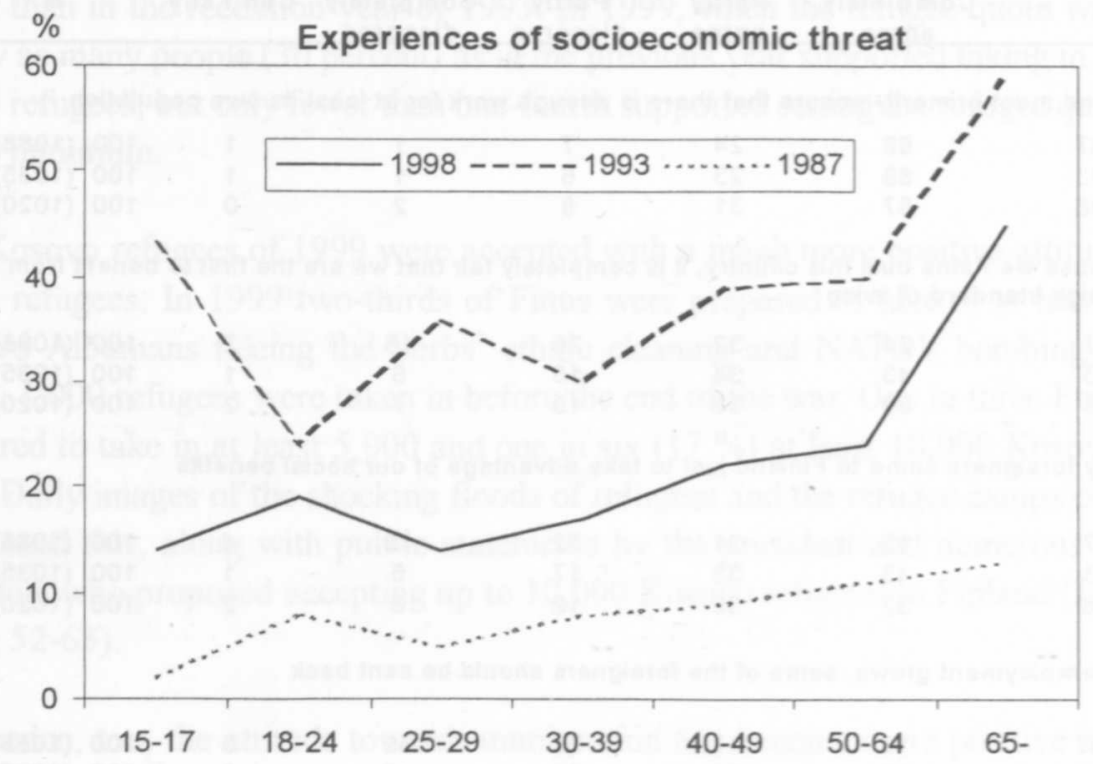

In Sweden, too, the socio-economic threat "caused" by immigrants was felt less strongly after the recession than during it (1993). Swedes (1995) and Finns (1998) also did not as often take their right to a high standard of living for granted, just because "we built this country." Both nationalities also supported less frequently "ethnic cleansing", which 
in this context means that as unemployment rises, some foreigners would have to be sent out of the country. However, Finns (1998) were significantly more likely than Swedes (1995) to support ethnic cleansing and felt they had an unequivocal right to jobs and a high standard of living, and were more likely to believe that "many foreigners come to this country just to take advantage of our good social benefits" (Lange 1995, 61-63). In 1998, Finns were somewhat more skeptical than Danes in the previous year, 1997, with regard to the use of social benefits by immigrants (Togeby 1997).

The findings point in the same direction in Norway, too, where the number of asylum seekers as well as unemployment reached their peak in 1993, although the unemployment rate was only a little over five percent. As unemployment and the number of asylum seekers declined, attitudes became more positive again. In 1997 for example, equal opportunities in employment among immigrants and Norwegians were emphasized more than before (1993), and it was thought that Norway should accept at least as many refugees and asylum seekers as "currently." The suspicion that immigrants could obtain social benefits more easily than Norwegians had also waned (Blom 1997, 9).

\section{Attitudes towards different nationality groups}

If Finnish attitudes were to be justified by competition for employment opportunities, one would think attitudes towards Ingrian Finns and Nordic people would be especially hostile - after all, they are best able to compete for jobs in a bilingual Finland. It might be thought that Estonians and English speakers would be better able to compete than speakers of languages that are more foreign to us.

Figure 3, however, shows that in 1998 Finns' attitudes were most positive towards the immigration of Ingrian Finns, Anglo-Saxons and Nordic people. The most negative attitudes were reserved against Russians, Arabs and Somalians. These nationality groups certainly have not taken away jobs from Finns, as the majority of their members are unemployed. Indeed, it is problematic that when they are unemployed, they are accused of living off of social security.

Attitudes towards all the nationality groups mentioned in the study were more positive in 1998 than during the recession year of 1993. Figure 4 shows that attitudes towards those in the upper strata of the ethnic hierarchy, for example Swedes, were even more positive than in 1987. Attitudes towards those at the lower end of the hierarchy, however, were more negative than in 1987. In other words, the stratification of ethnic hierarchy was even more pronounced. 
Figure 3. Attitudes to the immigration of different nationalities in 1998 (\%).

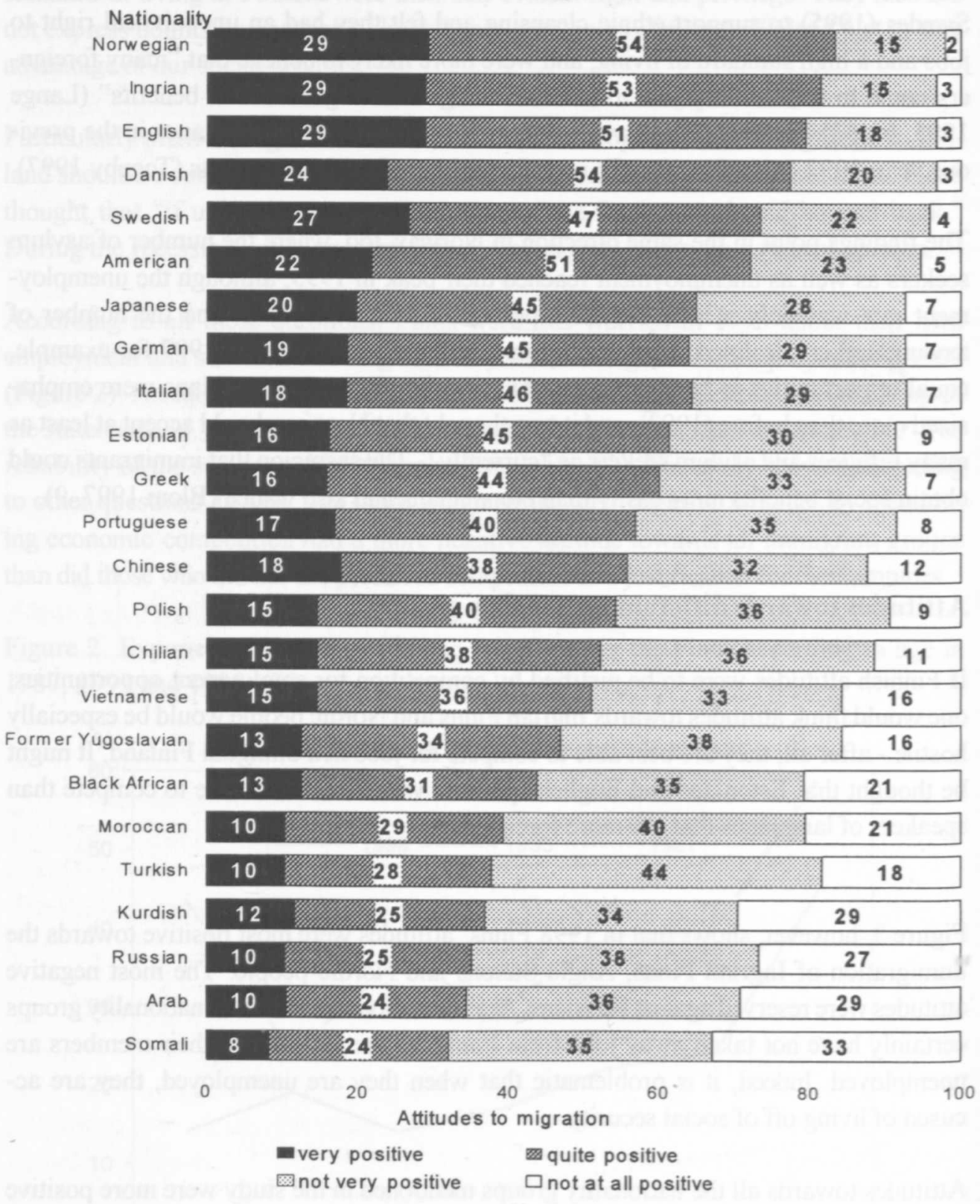

Particularly notable is the drop in the popularity of Russians after 1987. In 1998 they were at No. 22 in the hierarchy made up of 24 nationality groups. Nevertheless, attitudes towards Russians were more positive than during the recession in 1993. With regard to Russians moving to Finland, in 1987 a little over half, in 1993 only one out of four, and in 1998 a little over one-third of respondents felt they "would like it greatly or would like it somewhat." The relative position of Estonians also dropped from third to ninth place. Nonetheless, in 1998 nearly two-thirds of Finns felt they "would like it 
greatly or would like it somewhat" when asked about Estonians moving to Finland, and the proportion of those with a positive attitude was greater than during the recession (Jaakkola 1999, 84-86, 209).

Figure 4. Very or quite positive attitudes to the immigration of some nationalities in 1987, 1993 and 1998 (\%).

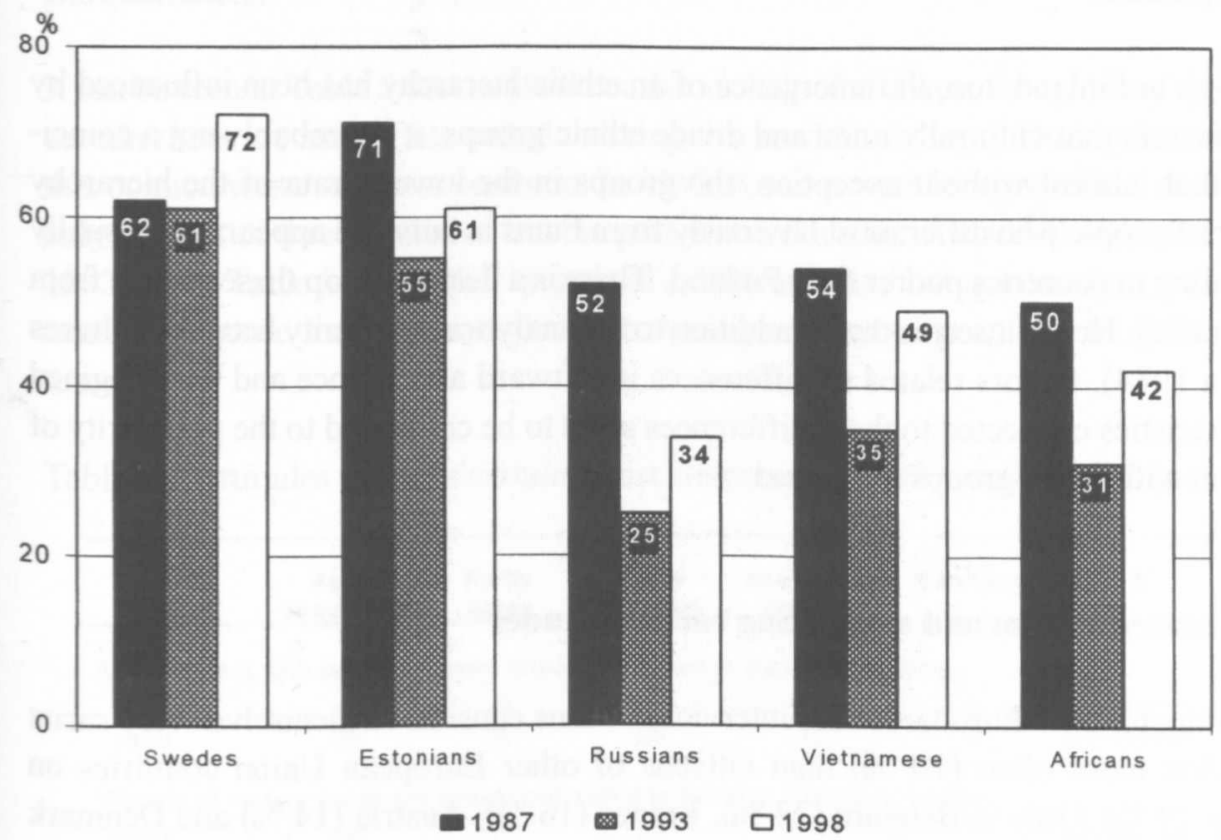

Attitudes towards marrying members of different nationality groups were more negative than were attitudes towards their immigration. Marrying a Somalian was considered even more negative than marrying a Romany, who have traditionally been the object of the most negative attitudes (Jaakkola 1989, 119; 1999, 84).

\section{Are Finns racist?}

The crystallization of the ethnic hierarchy is illustrated by the fact that from year to year, Finns' attitudes towards various nationality groups remain quite similar. Attitudes towards people from countries poorer than Finland who differ in outward appearance and culture from Finnish people, have consistently been more negative than attitudes towards immigrants who resemble us more closely.

The ranking order of ethnic groups was very similar compared to international studies, including one that revealed the ethnic hierarchy in Sweden (Lange and Westin 1993, 133-134). In Sweden and Finland there is an appreciation for 'one's own kind' over others. Miles $(1994,21)$ notes that it is not racist in itself to claim that it is 'natural' to 
think of 'one's own kind' as superior, although the truthfulness of this claim should be questioned. It is problematic that "it contains an explicit justification of the process of preferenc and of discrimination: giving preference means setting up a ranking system ... which unavoidably translates into rebuffing some other thing, person or group. In a debate on racism, then, it is significant which criteria are used to categorize 'one's own kind,' and consequently 'the Other,' as this is how preference and discrimination are then explained."

Although in Finland, too, the emergence of an ethnic hierarchy has been influenced by many factors that culturally unite and divide ethnic groups, it is probably not a coincidence that, almost without exception, the groups in the lower strata of the hierarchy consist of people who differ most obviously from Finns in outward appearance, usually originating in countries poorer than Finland. There is a desire to stop these groups from immigrating. Hence it seems that in addition to the analytical similarity between cultures (Westin 1984), factors related to differences in outward appearance and the imagined characteristics connected to these differences seem to be connected to the popularity of different nationality groups in Finland.

\section{Self-assessed racism and supporting racist attitudes}

According to 1997 Eurobarometer interviews, Finns considered themselves very racist somewhat more often $(10 \%)$ than citizens of other European Union countries on average (9\%). Only in Belgium (22\%), France (16\%), Austria (14\%) and Denmark (12\%) there were more people who defined themselves on a scale of 1 to 10 as between 7 and 10, meaning very racist. A little over one in five Finns (22\%) but over one-third of all Europeans (34\%) felt they were not racist at all (European Commission 1997,6). The present study uses the same scale. According to the scale, $12 \%$ of all Finns considered themselves very racist in 1998, $26 \%$ felt they were fairly racist, $41 \%$ somewhat racist and $18 \%$ did not consider themselves racist at all. It is reminiscent of the pluralistic ignorance known in sociology that the interviewees considered themselves less racist than other Finns.

Self-assessed racism is not the same thing as the racist attitudes observed in studies. Analyzing Finns' responses to the Eurobarometer questions, their attitudes in 1997 were less racist than those of Europeans on average. For example, Finns were less likely ( $20 \%)$ than Europeans on average ( $43 \%$ ) to believe that "legally established immigrants from outside the European Union should be sent back to their country of origin if they are unemployed." Danes were much harsher in this respect, compared with Finns and Swedes (European Commission 1997, p.24).

When comparing the attitudes of Finns and other Europeans, it must be take into account that there were less foreigners in Finland in absolute and relative terms than in 
any other country in the European Union, with the exception of the relative proportion of foreigners living in Italy. Also, the findings of the Eurobarometer cannot be compared directly with the findings of the present study, because the Eurobarometer required respondents to either clearly agree or disagree with the statement presented. In the present study, respondents were able to choose among four degrees of "agree fully/ in part/disagree," which made it possible to express more gradated views than in the Eurobarometer.

It can be seen in Table 5 that in 1998 nearly one half of all Finns thought that "people of certain races are simply not suited to living in a modern society." During the recession this opinion was even more common. In 1993, Swedes were less prejudiced than Finns: only one out of three agreed at least in part with such a racist claim (Lange and Westin 1993, 132). Table 5 shows that 'people of a different race' living in modern society was considered more inappropriate than the mixing together of people from different cultures.

Table 5. Attitudes towards certain racist statements in 1993 and 1998 (\%)

\begin{tabular}{|c|c|c|c|c|c|c|}
\hline & $\begin{array}{c}\text { Agree } \\
\text { completely }\end{array}$ & $\begin{array}{l}\text { Partly } \\
\text { agree }\end{array}$ & $\begin{array}{c}\text { Partly } \\
\text { disagree }\end{array}$ & $\begin{array}{c}\text { Completely } \\
\text { disagree }\end{array}$ & Can't say & $\mathbf{N}$ \\
\hline \multicolumn{7}{|c|}{ All foreigners who commit crimes should be forced to leave the country } \\
\hline $\begin{array}{l}1993 \\
1998\end{array}$ & $\begin{array}{l}45 \\
33\end{array}$ & $\begin{array}{l}23 \\
31\end{array}$ & $\begin{array}{l}22 \\
25\end{array}$ & $\begin{array}{c}8 \\
10\end{array}$ & $\begin{array}{l}1 \\
2\end{array}$ & $\begin{array}{l}100(1035) \\
100(1020)\end{array}$ \\
\hline \multicolumn{7}{|c|}{ *People of certain races are simply not suited to living in a modern society } \\
\hline $\begin{array}{l}1993 \\
1998\end{array}$ & $\begin{array}{l}20 \\
12\end{array}$ & $\begin{array}{l}31 \\
30\end{array}$ & $\begin{array}{l}22 \\
19\end{array}$ & $\begin{array}{l}22 \\
33\end{array}$ & $\begin{array}{l}5 \\
6\end{array}$ & $\begin{array}{l}100(1035) \\
100(1020)\end{array}$ \\
\hline \multicolumn{7}{|c|}{ *The practice of Islam should not be allowed in Finland because it threatens our culture } \\
\hline $\begin{array}{l}1993 \\
1998\end{array}$ & $\begin{array}{l}15 \\
12\end{array}$ & $\begin{array}{l}13 \\
16\end{array}$ & $\begin{array}{l}25 \\
24\end{array}$ & $\begin{array}{l}41 \\
42\end{array}$ & $\begin{array}{l}6 \\
6\end{array}$ & $\begin{array}{l}100(1035) \\
100(1020)\end{array}$ \\
\hline
\end{tabular}

We must admit the fact that certain peoples are more intelligent than others

$\begin{array}{lllllll}1998 & 12 & 22 & 20 & 41 & 5 & 100(1020)\end{array}$

*It is better for society if people from different cultures live separated and do not mix together

$\begin{array}{lllllll}1998 & 5 & 14 & 30 & 46 & 4 & 100(1020)\end{array}$

People whose appearance and culture are very different from the Finnish one are unpredictable and frightening

$\begin{array}{lllllll}1993 & 7 & 16 & 32 & 42 & 2 & 100(1035) \\ 1998 & 3 & 14 & 28 & 52 & 4 & 100(1020) \\ 1998 & 8 & 16 & 27 & 44 & 5 & 100(1020)\end{array}$

*It is against the laws of nature for people of different races to have children together
1998
3
10
19
66
3
100 (1020)

It is acceptable to take part in a demonstration organized against foreigners

$\begin{array}{lllllll}1998 & 8 & 16 & 27 & 44 & 5 & 100(1020)\end{array}$

I approve of the skinheads' activities against foreigners

$\begin{array}{lllllll}1998 & 2 & 7 & 13 & 75 & 2 & 100(1020)\end{array}$

* Part of the racism scale 
Racist is the appropriate term for the one out of seven Finns who at least partly agreed with the statement that "it is against the laws of nature for people of different races to have children together." Up to one out of four respondents agreed at least in part that some peoples are more intelligent than others. Nearly one-fifth agreed at least in part with a neo-racist view according to which "it is better for society if people from different cultures live separated and do not mix together." Over one-fourth agreed at least in part with the statement that "The practice of Islam should not be allowed in Finland because it threatens our culture." However, significantly fewer agreed fully with all the racist claims.

Finns also require that foreigners be more law-abiding than they. Nearly two-thirds of the respondents felt at least in part that "all foreigners who commit a crime should be forced to leave the country." Swedes were much harsher in this respect in 1995 than Finns were in 1998 (Lange 1995, 62).

Besides, nearly one out of ten Finns fully ( $2 \%$ ) or in part ( $7 \%$ ) accepted skinhead activities against foreigners. The support for racist statements did decline between the recession year of 1993 and 1998 (Table 5).

\section{Factors that explain attitudes towards foreigners in different population groups}

In each study year, women in Finland had a more positive attitude than men towards refugees accepted on humanitarian grounds, starving people from developing countries, and adoptive children. Men's attitudes were more positive than women's with regard to the arrival of foreigners who are 'useful' to Finns - restaurant owners, scientists and experts, athletes and tourists. Men also felt more frequently than women that "Finland should accept primarily educated foreigners." But men felt only a little more frequently than women that "Finnish women are too easily attracted to foreign men." Men were significantly more likely than women to support all the racist claims in Table 5.

Attitudes were most negative among young boys and pensioners. However, the difference along gender lines in 1998 with regard to attitudes towards refugees was greatest among the youngest age group: only three percent of 15-17-year-old boys, but over one-third of the girls, thought that Finland should take in more refugees than currently. Nearly half of the boys but only one in six girls wanted less refugees taken in than before. The distribution of men's attitudes towards refugees was in a linear curve, so that the attitudes with regard to taking in refugees of young men and the oldest men were more negative than the attitudes of anyone else. Among women, negativity towards refugees increased linearly in older age groups (Figure 5). 
Figure 5. Positive attitudes to the reception of refugees according to age and sex in 1998 (\%).

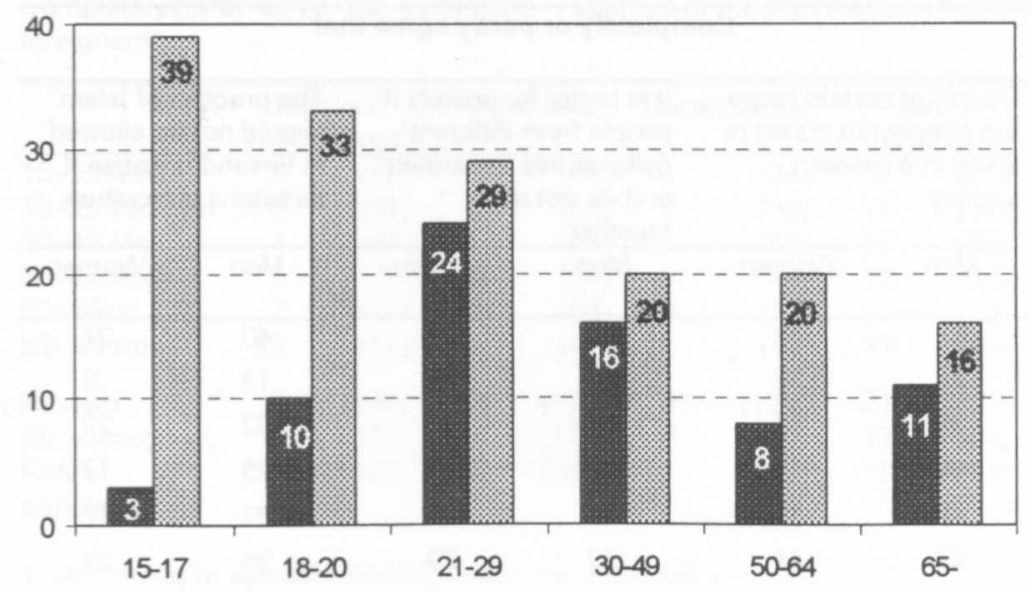

Finland should take in much more/somewhat more refugees than currently

줍 Men 중 Women

Young boys' attitudes towards foreign jobseekers were more negative than those of girls. This can be seen in the proportion of those who want "much less than currently/ somewhat less than currently" of an alien workforce. Half of the 15-17-year-old and 18-20-year-old boys, but only a little over a third of the girls of the same age groups, wanted Finland to take in less jobseekers from abroad than currently. Young boys and pensioners experienced immigrants as competitors for jobs and social benefits more frequently than young girls. One out of five 15-17-year-old boys, for example, "completely" agreed that "if unemployment rises, some foreigners have to be sent back from Finland." Only $4 \%$ of the girls supported such harsh ethnic cleansing.

Young boys also considered themselves significantly more racist than girls, and were more likely to support racist attitudes. Female pensioners, on the other hand, were less likely than women on average to think of themselves as racist, but their attitudes were actually the most racist. The distribution that illustrates men's racist attitudes curved linearly, similarly with the attitudes towards refugees, in that racist statements received most support among the youngest and oldest men. Among women also the support for racist attitudes increased with age. Racism was measured with a sum scale based on six racist statements, with a high reliability (Cronbach's alpha=.81 see Table 5 ). The high scores on the racism scale had a significant connection to negative attitudes towards accepting refugees and foreign jobseekers. 
Table 6. Support for certain racist statements according to age and gender 1998 (\%).

\section{Completely or partly agree that}

\begin{tabular}{lcccccc}
\hline & $\begin{array}{l}\text { People of certain races } \\
\text { are simply not suited to } \\
\text { living in a modern } \\
\text { society }\end{array}$ & $\begin{array}{l}\text { It is better for society if } \\
\text { people from different } \\
\text { cultures live separated } \\
\text { and do not mix } \\
\text { together }\end{array}$ & $\begin{array}{l}\text { The practice of Islam } \\
\text { should not be allowed } \\
\text { in Finland because it } \\
\text { threatens our culture }\end{array}$ \\
\cline { 2 - 7 } & 57 & 36 & Men & Women & Men & Women \\
\hline $15-17$ & 41 & 32 & 31 & 11 & 40 & 21 \\
$18-20$ & 39 & 37 & 17 & 10 & 13 & 9 \\
$21-29$ & 39 & 31 & 27 & 12 & 22 & 22 \\
$30-39$ & 43 & 36 & 24 & 10 & 33 & 17 \\
$40-49$ & 48 & 41 & 22 & 20 & 36 & 34 \\
$50-64$ & 57 & 42 & 27 & 32 & 40 & 40 \\
$65-$ & 47 & 37 & 36 & 16 & 32 & 25 \\
\hline Total & $(510)$ & $(510)$ & $(510)$ & $(510)$ & $(510)$ & $(510)$ \\
(N) & & & & & & 18 \\
\hline
\end{tabular}

Table 6 shows that young boys and pensioners were more likely to support the statement that "People of certain races are simply not suited to living in a modern society." They were also more likely to oppose the practice of Islam in Finland. Young men and elderly women were more likely than others to support neo-racism, according to which people from different cultures should not mix.

Boys in the Helsinki metropolitan area had the most positive attitudes and 15-20-yearold boys from rural areas had the most negative attitude towards foreign jobseekers Table 7). Attitudes towards refugees, too, were more positive among boys in the Helsinki metropolitan area than in other parts of the country. Boys in the Helsinki metropolitan area were also less likely than others to think of immigrants as competitors for jobs and social benefits, and were less racist in their attitudes than others.

Boys in rural areas are even more likely than urbanites to accept anti-foreigner skinhead activity. When the 15-29-year-olds were combined into a single group, it was observed that among the rural men of this age group, too, a high $36 \%$ supported at least in part "skinhead activity against foreigners", whereas the same figure for urban boys in the same age group was only $5 \%$, and for girls, only $6 \%$. In densely populated areas, young men, rural men over 30 and rural women over 50 were more accepting of skinhead activity than average (17-18\%). All in all, one out of six people living in rural areas ( $17 \%$ ), but only $4 \%$ of people living in the Helsinki metropolitan area accepted skinhead activity at least in part. 
Table 7. Approval of skinhead anti-foreigner activity according to age, gender and place of residence in $1998(\%)$.

Completely/partly agree with statement: "I approve of the skinheads' activities against foreigners"

\begin{tabular}{lrrrrrrrrrr}
\hline & \multicolumn{3}{c}{$\begin{array}{c}\text { Helsinki } \\
\text { metro area }\end{array}$} & \multicolumn{1}{c}{ Other city } & \multicolumn{2}{c}{ Rural, dense } & \multicolumn{2}{c}{$\begin{array}{l}\text { Rural, } \\
\text { sparse }\end{array}$} & All & N \\
\hline 15-29 Men & 5 & $(75)$ & 11 & $(62)$ & 18 & $(34)$ & 36 & $(31)$ & 16 & $(161)$ \\
15-29 Women & 6 & $(61)$ & 6 & $(63)$ & 7 & $(45)$ & 10 & $(31)$ & 7 & $(163)$ \\
30-49 Men & 1 & $(64)$ & 6 & $(64)$ & 6 & $(55)$ & 17 & $(49)$ & 10 & $(189)$ \\
30-Women & 1 & $(78)$ & 6 & $(64)$ & 5 & $(43)$ & 10 & $(4)$ & 6 & $(198)$ \\
50- Men & 7 & $(60)$ & 5 & $(58)$ & 6 & $(37)$ & 17 & $(35)$ & 9 & $(160)$ \\
50-Women & 12 & $(52)$ & 11 & $(45)$ & - & $(42)$ & 17 & $(40)$ & 8 & $(149)$ \\
All men & 5 & $(199)$ & 9 & $(174)$ & 9 & $(128)$ & 21 & $(115)$ & 11 & $(510)$ \\
All women & 3 & $(191)$ & 8 & $(172)$ & 4 & $(130)$ & 13 & $(119)$ & 7 & $(510)$ \\
Entire & 4 & $(390)$ & 8 & $(346)$ & 7 & $(258)$ & 17 & $(234)$ & 9 & $(1020)$ \\
population & & & & & & & & & &
\end{tabular}

1) According to special Helsinki metro area material

The majority ( $86 \%$ ) of skinhead supporters had finished only elementary, intermediate or comprehensive school. Over one-fifth ( $22 \%)$ were unemployed. Nearly a third were part of the working population, one in four was a student and one in six a pensioner.

According to the Youthbarometer, support for the skinheads declined between 1996 and 1997 from 15 to 11 percent among all 15-29-year-olds (Ministry of Education 1997). According to the present study, too, $11 \%$ of all 15-29-year-old Finns supported skinhead activity in 1998. However, the different phrasing of the questions complicates comparisons between the Youthbarometer and the present study.

In studies conducted in the Nordic countries and elsewhere in Europe it has been observed that positive attitudes towards foreigners are best explained by a high level of education. In Finland, too, those with the most education had the most positive attitudes towards immigrants from different countries, immigrating for different reasons, in all study years, including the recession. They were less likely to emphasize economic competition with immigrants, less likely to support racist statements, and more likely to condemn skinhead activity than those with little education. 
Figure 6. Attitudes to the reception of refugees according to the occupational status in $1998(\%)$.

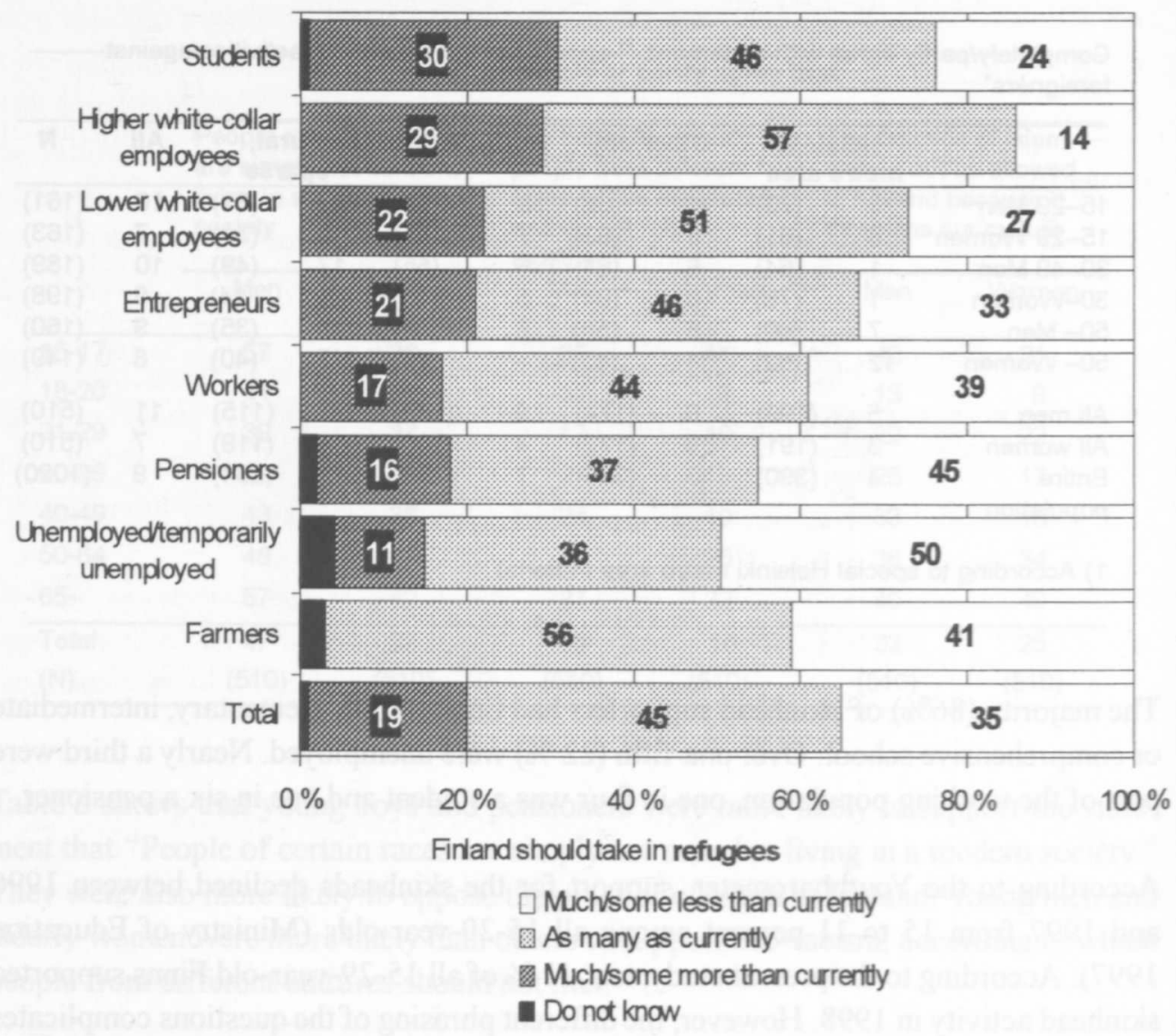

One explanation for the connection between education and attitudes towards foreigners is that schools strive to teach tolerance and provide knowledge about other cultures more than before. This may help prevent negative stereotyping. A long education improves cognitive competence and makes people more immune to anti-immigration propaganda. A higher education provides opportunities for material success and a sense of life control. Those with less education can instead take immigrants and blame their own frustrations on them. Besides, well-educated people know that tolerance towards immigrants is expected of them and know best how to conceal possible negative attitudes one may hope also when personally coming in contact with immigrants (Jenssen and Engesbak 1994).

Figures 6 and 7 show that students and upper and lower white-collar workers were more likely to believe that Finland should accept more refugees and foreign jobseekers. Entrepreneurs, too, had a more positive attitude than average towards foreign labor. The most negative attitude towards refugees and foreign workforce was held by farmers, the unemployed, pensioners and the working population. Besides, more than half 
of the unemployed, pensioners and the working population, and less than half of the farmers believed at least in part that "if unemployment grows, some of the foreigners should be sent back from Finland."

Figure 7. Attitudes to the reception of foreign job-seekers according to the occupational status in $1998(\%)$.

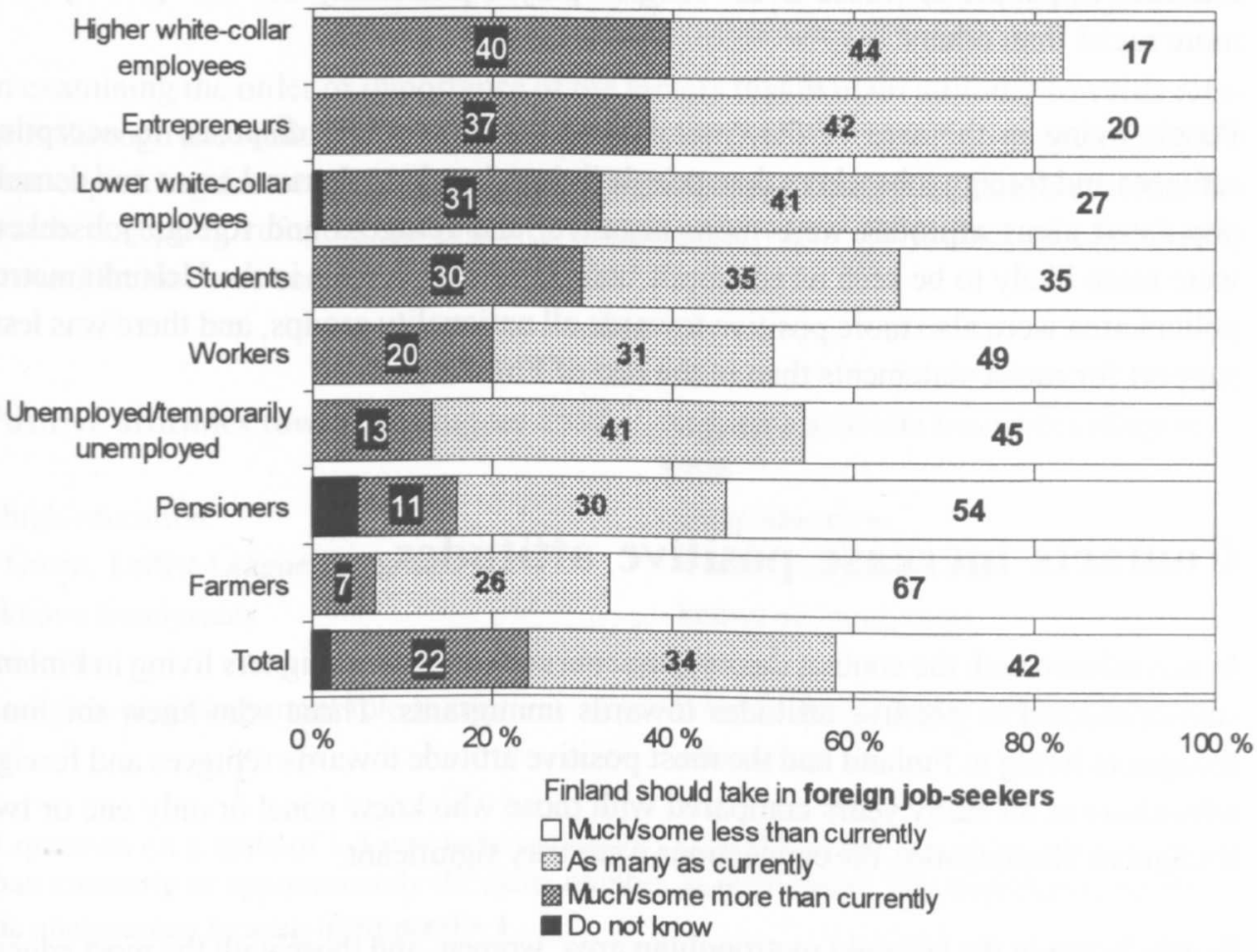

Green Party supporters were most favorably disposed and Conservative Party supporters were second-most favorably disposed to taking in refugees and foreign jobseekers. They were less likely than others to support racist attitudes and more likely to condemn anti-immigrant skinhead activities.

Attitudes towards refugees and foreign jobseekers became more positive within all political parties following the recession. With regard to refugees, this manifested itself only in the decline of the proportion of those who wanted less refugees than previously, and as an increase in support for the status quo, and the number of those who supported taking in as many refugees as currently. Only among supporters of the Conservative Party were there slightly more of those who felt that Finland should accept more refugees than previously. In 1998 and 1999, all parties wanted to accept more refugees than previously, compared to the year of mass unemployment, 1993. 
Religion, too, played a part in attitudes towards foreigners. The people in whose lives religion played a "very important role " $(14 \%)$ had a more positive attitude than others towards accepting all the immigrant groups mentioned in the study - with the exception of restaurant owners. Religious respondents were also less likely than others to be prepared to send foreigners back from Finland in case of an increase in unemployment. They were less likely than others to consider the living standard of refugees too high and were more prepared to permit foreigners the same standard of living as Finns. The attitudes of people in whose lives "religion played practically no role" $(15 \%)$ were more racist than others.

People living in the area of the capital were more favorably disposed to accepting refugees and foreign jobseekers than people living elsewhere. In rural areas and densely populated areas attitudes were more negative, and refugees and foreign jobseekers were more likely to be seen as economic competitors. Attitudes in the Helsinki metropolitan area were also more positive towards all nationality groups, and there was less support for racist statements than in the rest of Finland.

\section{Contacts increase positive attitudes}

In accordance with the contact theory, personal contact with foreigners living in Finland was connected to positive attitudes towards immigrants. Those who knew the most foreigners living in Finland had the most positive attitude towards refugees and foreign jobseekers in all study years compared with those who knew none, or only one or two foreigners. Statistically, the connections were very significant.

People living in the Helsinki metropolitan area, women, and those with the most education - with the most positive attitudes towards immigrants - also knew the most foreigners living in Finland. Over one-third of those who completed the old elementary school did not personally know any foreigners, whereas only close to one-fifth of those with at least the matriculation examination had absolutely no contacts among immigrants. Among occupational groups, upper white-collar workers were more likely than others to personally know immigrants, and pensioners and the unemployed were less likely to do so. The group most negatively disposed towards refugees and foreign jobseekers, 15-17-year-old boys and pensioners had less immigrant contacts than others.

Green Party supporters, most positively disposed towards foreigners, had the most immigrant contacts, whereas Social Democrats had the least: One out of five Greens but over a third of Social Democrats had no personal contacts among immigrants. Supporters of the Leftist League, on the other hand, had the largest number of people with numerous immigrant contacts, but they also came in second in having no immi- 
grant contacts at all. Half of the supporters of the Center Party knew no immigrants or knew a maximum of two.

\section{The order of importance of the factors that explain attitudes towards foreigners}

In examining the order of importance of the factors that explain attitudes towards refugees through the Multiple Classification Analysis (MCA), education proved to be the best explaining factor in all study years. The following factors explained attitudes towards accepting refugees, in order of importance, when the impact of other background factors was controlled:

\section{Positive attitudes towards refugees 1998}

- high education

- Green, Leftist League supporter

- knows immigrants

-woman

- religion plays important role in life
Negative attitude towards refugees 1998

- little education

- Center Party supporter

- knows no immigrants

-man

- religion does not play very important role in life

A question on a scale of 1-5 was to be explained: Should Finland accept more/less refugees than currently or approximately the same number as previously? The quantitative results of the analysis can be seen in Appendix 1.

Political party identification was the next-best explaining factor of attitudes towards refugees. Green Party supporters had the most positive attitude towards refugees, and Conservative Party supporters had the second-best attitude. But when education and other background factors were controlled, supporters of the Leftist League proved to be more favorably disposed to refugees than Conservative Party supporters. The lower level of education among Leftist League supporters thus explained their 'standing' behind the Conservative Party, before the education factor was controlled. After standardizing the education factor, the attitudes of Social Democrats, too, proved more positive than those of Conservative Party supporters. Attitudes among the Center Party towards refugees were more negative even after education was controlled.

Those with the most contacts among immigrants were, in accordance with the contact theory, more likely to have positive attitudes towards refugees, also after the effect of other background factors was controlled. Also, being a female or religious were inde- 
pendently connected to positive attitudes towards refugees. Age and the level of urbanization of the place of residence were closely connected to education, and they did not have an independent influence on attitudes towards refugees after the effect of education and other background factors were controlled.

A high level of education was also the best explaining factor for positive attitudes towards accepting foreign jobseekers in each study year. Living in the Helsinki metropolitan area came second. Personal contacts with immigrants were the third best explaining factor for positive attitudes towards foreign jobseekers.

The well-educated, upper white-collar workers and entrepreneurs had a more positive attitude towards accepting foreign jobseekers than did the less-educated, farmers and the working population. The unemployed/laid-off, in accordance with the conflict theory, were more likely than employed people to oppose accepting foreign labor, also after the effect of other background factors was controlled. Age, sex and religion did not explain attitudes when the effect of other background factors was controlled.

\section{Attitudes towards foreign jobseekers in 1998}

\section{Positive}

- high education

- lives in Helsinki metro area

- knows immigrants

- upper white collar, enterpreneur

- supporter of Green, Conservative or

Social Democratic Party

\section{Negative}

- little education

- lives in rural area or densely populated municipality

- knows no immigrants

- farmer or worker, unemployed

- supporter of Center Party or Leftist League

The quantitative results of the analysis are in Appendix 2.

Supporters of the Green, Conservative and Social Democratic Parties were more likely to have a positive attitude towards foreign jobseekers, also when the connection of other background factors to the results was controlled. Attitudes towards refugees and foreign jobseekers, then, were not determined by supporting a particular party. Living in the Helsinki metropolitan area increased positive attitudes towards foreign jobseekers only, not towards refugees. Being a woman or religious had a positive effect only with regard to attitudes towards refugees accepted on humanitarian grounds.

The factors that best explained the view that foreigners compete with Finns for jobs and social benefits were a low level of education, pensioner status and unemployment. Supporting a particular political party was the third-best explaining factor. The Green and Conservative Party supporters were less likely than others to view immigrants as 
competitors for jobs and social benefits. This had to do with the higher education level of Conservative Party supporters and/or other background factors, not party ideology. When the effect of other background factors was controlled, both Center and Conservative Party supporters were more likely than Green Party, Leftist League or Social Democrat supporters to hold the view that foreigners competed with Finns for jobs and took advantage of social benefits.

Men and people with no contact with immigrants emphasized economic competition more often than other people. Competition was emphasized less in the Helsinki metropolitan area than in the rest of Finland, even after other background factors were controlled. Pensioners were more likely than younger people to view foreigners as competitors for jobs and social benefits. This, however, had to do with their lower educational level and/or other background factors, because age was not connected to perceived competition when the effect of other background factors was controlled.

The combined material of 1987, 1993 and $1998(\mathrm{~N}=3143)$ showed that the year of study, in accordance with the conflict theory, explained the perception of economic competition also when the effect of other background factors was controlled. In the recession year of 1993, immigrants were more likely to be seen as competition for jobs and as taking advantage of social benefits, than in 1987 and 1998, both years of economic boom.

A low level of education was also the best explanation for supporting racist statements. Little contact with immigrants was the second-best explaining factor. Men were more likely to support racist claims than women.

\section{Supported racist attitudes most 1998}

- little education

- knows no immigrants

- man

- Center or Conservative Party supporter

- lives in rural area

\section{Supported racist attitudes least 1998}

- at least matriculation examination

- knows immigrants

- woman

- Green Party, Leftist League, Social Democrat supporter

- lives in city

The factors predicting the racism scale's values are presented quantitatively in Appendix 3 .

Supporters of the Green and Conservative parties had the least racist attitudes. The anti-racism of Leftist League supporters was not observed until education was controlled. After that, Conservative Party supporters proved more racist than supporters of the Green Party, Leftist League or Social Democrats. The racist attitudes of Leftist League supporters and Social Democrats, then, were explained by their lower education level, not party ideology. Center Party supporters and people living in rural areas 
were more likely than others to support racist statements. The fact that older generations were more likely than younger people to concur with racist statements was a result of their lower level of education and/or other background factors. When they were controlled, the connection between age and racism disappeared.

Men and people in rural areas were also more likely than other people to approve of the skinheads' anti-foreigner activity. Those who completed intermediate or comprehensive school were more likely to support skinhead activity than those who only completed the old primary school or those who took their matriculation examination, when the effect of other background factors was controlled.

Attitudes towards foreigners among skinhead supporters were consistent. They were more negative towards immigration and were more likely than other people to see foreigners as competing with Finns for jobs and social benefits. Their opinions were more racist than other people's and they were less likely to think that "the police should intervene in racist violence more effectively than currently" and that "attacks against immigrants should be punished more severely than currently." Two-thirds of skinhead supporters had a negative attitude towards immigrants acting as police officers, whereas over half of all Finns had a positive or fairly positive attitude with regard to this issue (Jaakkola 1999, 140).

To summarize, it may be observed that in accordance with the contact theory, a high level of education and plentiful personal contact explained a positive attitude towards refugees and foreign jobseekers, as well as the scarcity of racist attitudes when the effect of other background factors was controlled. Those with the least amount of education and those who did not know any immigrants were more likely to view them as competitors for jobs and as taking advantage of social benefits.

In accordance with the conflict theory, unemployment explained negative attitudes towards foreign jobseekers and seeing immigrants as competition for jobs and social benefits. However, it did not explain the negative attitude towards refugees, or racist attitudes. Women are more likely to have a positive attitude towards refugees, less likely to emphasize economic competition, and less likely to support racist attitudes than men, even after the effect of education and other background factors are controlled. Religiosity was connected only to positive attitudes towards refugees. 


\section{Discussion}

The study indicates that economic prosperity clearly influences attitudes towards foreigners. Anti-foreign sentiment was significantly more common in 1993 during the economic recession and mass employment - coinciding unexpectedly with a greater than before influx of asylum seekers to Finland - than during the economic boom in 1987 that preceded it, when there were very few foreigners in Finland. Anti-immigrant sentiment declined with an improving employment situation and economic recovery by

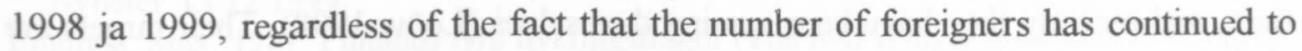
grow. If the employment situation in Finland remains the same or improves and if the predicted labor shortage occurs, attitudes may continue to become more positive, as long as there is no sudden surge in immigration. The increase in education and contacts as well as urbanization may help increase tolerance. As Europe becomes unified, more and more Finns ( $17 \%$ ) identify themselves as European as well, and it is part of the European identity to have positive attitudes towards foreigners (Jaakkola 1999, 110-116).

Although a rather crystallized ethnic hierarchy prevails in Finland, the attitude towards all population groups is more positive today than during the recession. A negative attitude towards different-looking representatives of faraway cultures, such as Somalians and the largest immigrant group, Russians, is still alarmingly common. Attitudes towards foreigners were most negative among young boys and the oldest men and women in rural areas. They had little contact with immigrants and their opinions are probably basically based on hear-say and sensationalistic articles on immigrants. It is especially alarming that over one-fifth of all 15-20-year-old boys and over one-third (36\%) of 15-29-year-old men in rural areas approved at least in part of the anti-foreigner activity of skinheads.

Based on racist attitudes and the support for skinheads, it seems that in Finland too there is fertile ground for the growth of anti-immigrant political parties, which have been successful in countries which have taken in a much greater number of immigrants than Finland. The small extreme-right groups operating in Finland, such as "the patriotic national alliance", "the patriotic right", "the national radical party" and "the national democratic party", have not been able to register as parties because of a scarcity of supporters (Rislakki 1995; Helsingin Sanomat Aug. 10 and 11, 1999; Pekonen 1999).

Although attitudes within the registered political parties vary with regard to immigrant issues, in 1998 all parties signed the EU-initiated charter by all European political parties for a racism-free society. It includes a covenant to ascertain that all forms of racial discrimination and incitement to racial hatred in election campaigns and other political activities are rebuffed. According to the recommendation of the UN committee for ending racial discrimination, "Finland's criminal law should pronounce unlawful and ban organizations that support racist activities" (Ministry of Foreign Affairs 1999). 
Anti-immigrant political parties in France, Germany, Austria, Switzerland, Italy, Belgium, Denmark and Norway have received between 10 and 27 percent of votes in recent elections. The Progress Party led by Carl I. Hagen is already Norway's largest conservative party. Jörg Haider's Freedom Party in Austria and the Folk Party led by millionaire Christoph Blocher in Switzerland are the second-largest parties in their respective countries. Austria's Freedom Party entered the Austrian government in February 2000 and got half of the government posts.

In Sweden, many underground Nazi organizations have already been active for a long time, and recently they have been arming themselves (Lööw 1998). Their targets are no longer just dark-skinned immigrants. In 1999, Nazis murdered two police officers, and a union leader who criticized their activities, and they set a bomb in the car of a journalist couple, injuring one of the journalists and the couple's small son. These events have spurred a lively debate in Sweden concerning the banning of Nazi organizations, which is already supported by nearly three-fourths of all Swedes, according to the latest studies by Sifo. However, permitting Nazi organizations to exist is defended on the basis of freedom of speech and assembly (Diaz 1999a, Diaz 1999b; Jokisalo 1999; Nycander 1999; Messing \& Lindahl 1999; Helsingin Sanomat Oct. 13; Oct. 15; Oct. 24, 1999; Dagens Nyheter Oct. 16; Oct. 20; Oct. 22; Oct. 24, 1999). But in November 13, 1999, the four largest daily newspapers in Sweden published the photographs of 56 Nazis, stating among other reasons that "one out of three prosecutors have been forced to discontinue their investigations, because some of the parties to the crime were frightened into silence." There are many among the police who have stated that they do not dare interfere with crimes committed by Nazis, because they are afraid of consequences to their families (Dagens Nyheter Nov. 30, 1999).

Although the attitudes of regular Finns have become more positive following the recession, Finland, too, has seen the number of racist crimes double between 1997 (194) and 1998 (414) (Ministry of the Interior, 1999). The activities of Nazi and other racist organizations may spread to Finland through channels like the Internet or white-power music (Lööw 1998; Brå-rapport 1999). Tolerance and respect for human rights should be taught especially to young Finnish men.

A case study on the attitudes towards refugees from Kosovo in 1999 indicated that attitudes towards refugees can become more positive very rapidly when there is plenty of information available concerning the situation in the place where the refugees originate, and concerning their distress and need for aid, and when political leaders stress the obligation Finland has to save refugees from being trampled by war. 


\section{References}

Blom, Svein. 1997. Holdning til innvandrere og innvandringspolitikk (Attitudes towards immigrants and immigration policies). Spørsmål i SSBs omnibus i mai/juni 1997. Notater 97/54. Oslo: Statistics Norway.

Brå-rapport. 1999. Vit maktmusik (White Power music). Brå-rapport 1999:10. Stockholm: Brottsförebygganderådet.

Diaz, Jose Alberto. 1999a. "Folket för naziförbud" ("People for a ban on Nazis"). Dagens Nyheter 23.10.1999b.

-. 1999b. "Allt fler för ett nazistsförbud" ("Increasing support for a ban on Nazis"). Dagens Nyheter 13.12.1999.

Engman, Max. 1987. Finlands fyra flyktingsfrågor (The four refugee questions in Finland) HBL-forum. Hufvudstadsbladet 26.4.1987.

European Commission. 1997. Racism and xenophobia in Europe. Eurobarometer Opinion Poll No 47.1. Luxembourg.

Gaasholt, Øystein and Lise Togeby. 1995. I syv vind. Danskernes holdninger till flygtninge og indvandrere (Danish attitudes towards refugees and immigrants). Aarhus universitet, Institut for Statskundskab. Aarhus: Forlaget Publica

Hernes, Gudmund and Knud Knudsen. 1994. Klimaskifte? Norske reaktioner på flyktninger, asyls $ø$ kere og innvandrere 1988-1993 (Climate change? Norwegian reactions on refugees, asylum seekers and immigrants in 1988-1993). Tidskrift for samfunnsforskning 3: 319343.

Jaakkola, Magdalena. 1989. Suomalaisten suhtautuminen ulkomaalaisiin ja ulkomaalaispolitiikkaan (The attitudes of Finns towards foreigners and immigration policy). Työvoimaministeriö, Siirtolaisuustutkimuksia 21. Helsinki: Työvoimaministeriö, Valtion painatuskeskus.

-. 1994. Ulkomaalaisasenteet Suomessa ja Ruotsissa (Attitudes towards foreigners in Finland and Sweden). In: Maahanmuuttajat. Kulttuurien kohtaaminen Suomessa, edited by Karmela Liebkind, pp. 50-81. Helsinki: Gaudeamus.

-. 1995. Suomalaisten kiristyvät ulkomaalaisasenteet (Hardening attitudes towards foreigners in Finland). Työminisțeriö, Työpoliittinen tutkimus 101. Helsinki: Työministeriö.

- 1999. Maahanmuutto ja etniset asenteet. Suomalaisten suhtautuminen maahanmuuttajiin 1987-1999 (Immigration and ethnic attitudes. Finnish attitudes towards immigrants in 1987-1999). Työministeriö, Työpoliittinen tutkimus 213. Helsinki: Edita.

Jenssen, Anders Todal and Heidi Engesbek. 1994. The many faces of education: why are people with lower education more hostile towards immigrants than people with higher education? Scandinavian Journal of Educational Research 38:1, 33-50.

Kero, Reino. 1986. Suomen siirtolaisuuden historia I (The history of Finnish migration I). Julkaisuja No. 10. Turku: Turun yliopiston historian laitos.

Lange, Anders. 1995. Den svårfångade opinionen. Förhållningssätt till invandring och invandrare 1995 (The opinion difficult to be perceived. Attitudes towards immigration and immigrants 1995). Centrum för invandringsforskning (CEIFO). Stockholm: Stockholms universitet.

Lange, Anders and Charles Westin. 1981. Etnisk diskriminering och social identitet (Ethnic discrimination and social identity). Stockholm: LiberFörlag, Publica.

Lange, Anders and Charles Westin. 1993. Den mångtydiga toleransen. Förhållningssätt till invandring och invandrare 1993 . (The tolerance has many meanings. Attitudes towards immigration and immigrants 1993). Centrum för invandringsforskning. Stockholm: Stockholms universitet. 
Liebkind, Karmela and Alfred McAlister. 1999. Extended contact through peer modelling to promote tolerance in Finland. European Journal of Social Psychology 29 (5-6): 765780 .

Liebkind, Karmela, Juha J. Haaramo and Inga Jasinskaja-Lahti. 2000. Effects of contact and personality on intergroup attitudes of different professionals. Journal of Community and Applied Social Psychology (in press).

Lööw, Helene. 1998. Nazismen i Sverige 1980-1997. Den rasistiska undergroundrörelsen: musiken, myterna, riterna (The racist underground movement: music, myths, rites). Stockholm: Ordfront förlag.

Messing, Ulrica and Kent Lindahl. 1999. "Rasismens offer får ökat stöd" ("Victims of racism get increased support"). Dagens Nyheter 27.10.

Miles, Robert. 1994. Rasismi (Racism). Tampere: Vastapaino.

Nycander, Svante. 1999. I stället för ett nazistförbud (Instead of a ban on Nazis). Dagens Nyheter 20.10.1999.

Opetusministeriö. 1997. Nuorisobarometri 2 (Youthbarometer 2). Nuoran julkaisuja 3. Helsinki: Nuorisoasiain neuvottelukunta.

Pekonen, Kyösti. 1999. Suomi poikkeuksena? Uusi radikaali oikeisto Euroopassa ja Suomessa (Finland an exception? The new radical right in Europe and in Finland). Tieteessä tapahtuu 5, 15-18.

Rislakki, Jukka. 1995. Äärimmäisenä oikealla (On the extreme right). Helsingin Sanomat 11.6.1995, D 6-7.

Sifo. 1999. Samhällsbarometern 1999 (Societal Barometer 1999). Stockholm: Sifo Research and Consulting.

Sisäasiainministeriö. 1999. Poliisin tietoon tullut rasistinen rikollisuus Suomessa 1998 (Racist criminality reported to the police in Finland in 1998). Poliisihallinnon julkaisu 11. Helsinki: Sisäasiainministeriö.

Trankell, Arne. 1974. Svenskars fördomar mot invandrare (Swedes' prejudices against immigrants). In: Invandrarutredningens huvudbetänkande, bilaga 4, Statens offentliga utredningar (SOU) 1974:70, 121-212.

Työministeriö. 1998. Inkerinsuomalaisten maahanmuutto Suomeen 1990-luvulla (Ingrian Finns' immigration to Finland in the 1990s). Työhallinnon julkaisu 215. Helsinki: Työministeriö.

Westin, Charles. 1984. Majoritet om minoritet. En studie i etnisk tolerans i 80-talets Sverige (The majority on the minority. A study of ethnic tolerance in Sweden in the 1980s). Stockholm: LiberFörlag.

-. 1987. Den toleranta opinionen. Inställningen till invandrare 1987 (The tolerant opinion. Attitudes towards immigrants in 1987). Rapport nr 8 från Delegationen för invandrarforskning (DEIFO). Stockholm. 
Appendix 1. Factors predicting positive attitudes ${ }^{1}$ towards refugees according to an MCA analysis in 1998.

\begin{tabular}{|c|c|c|c|c|c|}
\hline \multirow[b]{2}{*}{ Age } & \multicolumn{3}{|c|}{ Unadjusted } & \multicolumn{2}{|c|}{ Adjusted for factors } \\
\hline & $\mathbf{N}$ & & Eta & & Beta \\
\hline $15-19$ & 116 & .02 & & .00 & \\
\hline $20-29$ & 199 & .16 & & .07 & \\
\hline $30-39$ & 212 & .02 & & .02 & \\
\hline $40-49$ & 166 & .03 & & .05 & \\
\hline 65- & 100 & -.33 & .14 & -.19 & .08 \\
\hline \multicolumn{6}{|l|}{ Gender } \\
\hline Man & 498 & -.13 & & .02 & \\
\hline Woman & 493 & .13 & .13 & .09 & $.10^{\star *}$ \\
\hline \multicolumn{6}{|l|}{ Basic education } \\
\hline Basic, old comprehensive & 314 & -.21 & & .02 & \\
\hline Comprehensive school & 422 & -.10 & & -.10 & \\
\hline Matriculation examination & 255 & .43 & .26 & .26 & $.16^{* * *}$ \\
\hline \multicolumn{6}{|l|}{ Occupation } \\
\hline Upper white collar & 72 & .40 & & 14 & \\
\hline Lower white collar & 126 & .21 & & .04 & \\
\hline Worker & 238 & -.12 & & .02 & \\
\hline Entrepreneur & 51 & .02 & & .02 & \\
\hline Farmer & 16 & -.45 & & -.45 & \\
\hline Student & 177 & .26 & & .19 & \\
\hline Pensioner & 177 & -.25 & & .01 & \\
\hline Unemployed & 106 & -.16 & & .01 & \\
\hline Other & 28 & -.30 & .24 & -.45 & .14 \\
\hline \multicolumn{6}{|l|}{ Place of residence } \\
\hline Helsinki metro area & 181 & .14 & & .02 & \\
\hline City-type municipality & 335 & .02 & & .04 & \\
\hline Densely populated municipality & 250 & -.11 & & .02 & \\
\hline Rural-type municipality & 225 & -.12 & .12 & .02 & .03 \\
\hline \multicolumn{6}{|l|}{ Knows foreigners } \\
\hline None & 267 & -.24 & & -.16 & \\
\hline $1-2$ & 191 & .02 & & .06 & \\
\hline 3-5 & 244 & .10 & & .06 & \\
\hline $6-10$ & 150 & .02 & & .02 & \\
\hline More than 10 & 139 & .30 & .18 & .19 & $.13^{* *}$ \\
\hline \multicolumn{6}{|l|}{ Political party identification } \\
\hline Green Party & 81 & .50 & & .31 & \\
\hline Leftist League & 33 & .02 & & .20 & \\
\hline Social Democrats & 176 & .02 & & .06 & \\
\hline Conservative Party & 108 & .15 & & .02 & \\
\hline Center Party & 152 & .02 & & -.11 & \\
\hline Others & 108 & .15 & & .05 & \\
\hline \multirow[t]{2}{*}{ No political party affiliation } & 333 & -.11 & & .02 & $.12^{* *}$ \\
\hline & \multicolumn{5}{|c|}{ Religion } \\
\hline Very important role in life & 127 & .26 & & .26 & \\
\hline Somewhat/not very/not important & 864 & .02 & .10 & .02 & $.10^{* *}$ \\
\hline R2 & & & & & .146 \\
\hline R & & & & & .382 \\
\hline
\end{tabular}

'What is your attitude usually conceming the right of refugees to move to Finland; should Finland accept refugees much more than at present (5), somewhat more (4), approximately the same number as before (3), somewhat less (2) or much less (1)? 
Appendix 2. Factors predicting positive attitudes ${ }^{1}$ towards foreign jobseekers according to an MCA analysis in 1998.

\begin{tabular}{|c|c|c|c|c|c|}
\hline \multirow[b]{2}{*}{ Age } & \multirow[b]{2}{*}{$\mathbf{N}$} & \multicolumn{2}{|c|}{ Unadjusted } & \multicolumn{2}{|c|}{ Adjusted for factors } \\
\hline & & & Eta & & Beta \\
\hline $15-19$ & 118 & .02 & & .05 & \\
\hline $20-29$ & 198 & .13 & & .01 & \\
\hline $30-39$ & 211 & .14 & & -.01 & \\
\hline $40-49$ & 167 & .01 & & .06 & \\
\hline $50-64$ & 196 & .03 & & .05 & \\
\hline 65 & 96 & .56 & .18 & -.26 & .08 \\
\hline \multicolumn{6}{|l|}{ Gender } \\
\hline Man & 493 & .02 & (2) & -.01 & \\
\hline Woman & 493 & .06 & .06 & -.01 & .01 \\
\hline \multicolumn{6}{|l|}{ Basic education } \\
\hline Basic, old comprehensive & 310 & -.31 & & -.17 & \\
\hline Comprehensive school & 424 & .02 & & -.07 & \\
\hline Matriculation examination & 252 & .53 & .30 & .33 & $.18^{\circ * *}$ \\
\hline \multicolumn{6}{|l|}{ Occupation } \\
\hline Upper white collar & 72 & .54 & & .10 & \\
\hline Lower white collar & 125 & .38 & & .18 & \\
\hline Worker & 237 & -.16 & & -.10 & \\
\hline Entrepreneur & 51 & .42 & & .39 & \\
\hline Farmer & 17 & -.46 & & -.12 & \\
\hline Student & 178 & .16 & & .03 & \\
\hline Pensioner & 172 & -.37 & & -.07 & \\
\hline Unemployed & 105 & -.25 & & -.13 & \\
\hline Other & 29 & .02 & .28 & -.09 & $.13^{*}$ \\
\hline \multicolumn{6}{|l|}{ Place of residence } \\
\hline Helsinki metro area & 179 & .53 & & .31 & \\
\hline City-type municipality & 332 & .07 & & .03 & \\
\hline Densely populated municipality & 250 & -.26 & & -.17 & \\
\hline Rural-type municipality & 225 & -.23 & .27 &.$- \infty$ & $.15^{*+*}$ \\
\hline \multicolumn{6}{|l|}{ Knows foreigners } \\
\hline None & 264 & -.27 & & -.14 & \\
\hline $1-2$ & 190 & .02 & & .01 & \\
\hline $3-5$ & 244 & .05 & & -.07 & \\
\hline $6-10$ & 149 & .11 & & -06 & \\
\hline More than 10 & 139 & .45 & .21 & .30 & $.13^{* *}$ \\
\hline \multicolumn{6}{|l|}{ Political party identification } \\
\hline Green Party & 82 & .54 & & .25 & \\
\hline Leftist League & 33 & -.12 & & .00 & \\
\hline Social Democrats & 173 & -.02 & & .06 & \\
\hline Conservative Party & 106 & .31 & & .09 & \\
\hline Center Party & 152 & -.36 & & -.26 & \\
\hline Others & 108 & .09 & & -.01 & \\
\hline No political party affiliation & 332 & .02 & 22 & .00 & $.13^{\text {s* }}$ \\
\hline \multicolumn{6}{|l|}{ Religion } \\
\hline Very important role in life & 126 & .09 & & .07 & \\
\hline $\begin{array}{l}\text { Somewhat/not very/not important } \\
\text { R2 } \\
\text { R }\end{array}$ & 860 & .02 & .03 & -.01 & $\begin{array}{l}.02 \\
.189 \\
.435\end{array}$ \\
\hline
\end{tabular}


Appendix 3. Factors predicting racist attitudes according to an MCA analysis in 1998.

\begin{tabular}{|c|c|c|c|c|c|}
\hline \multirow[b]{2}{*}{ Age } & \multirow[b]{2}{*}{$\mathbf{N}$} & \multicolumn{2}{|c|}{ Unadjusted } & \multicolumn{2}{|c|}{ Adjusted for factors } \\
\hline & & & Eta & & Beta \\
\hline $\begin{array}{l}15-19 \\
20-29 \\
30-39 \\
40-49 \\
50-64 \\
65\end{array}$ & $\begin{array}{r}114 \\
198 \\
210 \\
166 \\
194 \\
91\end{array}$ & $\begin{array}{l}-.02 \\
-.11 \\
-.13 \\
-.02 \\
.12 \\
.34\end{array}$ & 21 & $\begin{array}{r}-.03 \\
.00 \\
-.03 \\
-.04 \\
.05 \\
.06\end{array}$ & .05 \\
\hline $\begin{array}{l}\text { Gender } \\
\text { Man } \\
\text { Woman }\end{array}$ & $\begin{array}{l}489 \\
484\end{array}$ & $\begin{array}{r}.11 \\
-.11\end{array}$ & .16 & $\begin{array}{r}.08 \\
-.08\end{array}$ & $.12^{*+*}$ \\
\hline $\begin{array}{l}\text { Basic education } \\
\text { Basic, old comprehensive } \\
\text { Comprehensive school } \\
\text { Matriculation examination }\end{array}$ & $\begin{array}{l}301 \\
419 \\
253\end{array}$ & $\begin{array}{r}.24 \\
.05 \\
-. .36\end{array}$ & .35 & $\begin{array}{r}.12 \\
.05 \\
-.23\end{array}$ & $.21^{\text {*****}}$ \\
\hline $\begin{array}{l}\text { Occupation } \\
\text { Upper white collar } \\
\text { Lower white collar } \\
\text { Worker } \\
\text { Entrepreneur } \\
\text { Farmer } \\
\text { Student } \\
\text { Pensioner } \\
\text { Unemployed } \\
\text { Other }\end{array}$ & $\begin{array}{r}72 \\
125 \\
232 \\
51 \\
16 \\
174 \\
167 \\
167 \\
107 \\
29\end{array}$ & $\begin{array}{l}-.37 \\
-.23 \\
.07 \\
.02 \\
-.12 \\
-.14 \\
.32 \\
.11 \\
-.06\end{array}$ & .30 & $\begin{array}{l}-.13 \\
-.08 \\
.02 \\
-.03 \\
-.15 \\
-.05 \\
.13 \\
.05 \\
.01\end{array}$ & .12 \\
\hline $\begin{array}{l}\text { Place of residence } \\
\text { Helsink metro area } \\
\text { City-type municipality } \\
\text { Densely populated municipality } \\
\text { Rural-type municipality }\end{array}$ & $\begin{array}{l}180 \\
332 \\
244 \\
217\end{array}$ & $\begin{array}{l}-.21 \\
-.08 \\
.16 \\
.13\end{array}$ & .22 & $\begin{array}{r}-.08 \\
-.05 \\
.09 \\
.06\end{array}$ & $.11^{* *}$ \\
\hline $\begin{array}{l}\text { Knows foreigners } \\
\text { None } \\
1-2 \\
3-5 \\
6-10 \\
\text { More than } 10\end{array}$ & $\begin{array}{l}259 \\
189 \\
239 \\
150 \\
136\end{array}$ & $\begin{array}{l}.22 \\
.01 \\
-.08 \\
-.09 \\
-.21\end{array}$ & .22 & $\begin{array}{l}.15 \\
-.02 \\
-.04 \\
-.06 \\
-.12\end{array}$ & $.14^{4+* *}$ \\
\hline $\begin{array}{l}\text { Political party identification } \\
\text { Green Party } \\
\text { Leftist League } \\
\text { Social Democrats } \\
\text { Conservative Party } \\
\text { Center Party } \\
\text { Others } \\
\text { No political party affiliation }\end{array}$ & $\begin{array}{r}82 \\
31 \\
173 \\
109 \\
148 \\
108 \\
322\end{array}$ & $\begin{array}{r}-.32 \\
.06 \\
.04 \\
-.14 \\
.23 \\
.03 \\
.01\end{array}$ & .21 & $\begin{array}{l}-.10 \\
-.08 \\
-.06 \\
-.02 \\
.17 \\
.02 \\
.01\end{array}$ & $.12^{*}$ \\
\hline $\begin{array}{l}\text { Religion } \\
\text { Very important role in life } \\
\text { Somewhat/not very/not } \\
\text { important } \\
\text { R2 } \\
\text { R }\end{array}$ & $\begin{array}{l}129 \\
844\end{array}$ & $\begin{array}{l}.02 \\
.00\end{array}$ & .01 & $\begin{array}{r}.03 \\
-.01\end{array}$ & $\begin{array}{l}.02 \\
.207 \\
.455\end{array}$ \\
\hline
\end{tabular}

